\title{
Effects of Instruction and Self-Monitoring on Adherence to Treatment of Juvenile Systemic Lupus Erythematosus
}

\author{
Flávia Pinho Almeida*, 1 \\ Orcid.org/0000-0003-4738-5537 \\ Eleonora Arnaud Pereira Ferreira ${ }^{1}$ \\ Orcid.org/0000-0001-9778-9295 \\ Ana Julia Pantoja de Moraes ${ }^{1}$ \\ Orcid.org/0000-0002-7435-2514
}

${ }^{1}$ Universidade Federal do Pará, Belém, Pará, Brasil

\begin{abstract}
This research evaluated the combined effects of instructions (through health education manual) and self-monitoring (using record forms) in occurrence of adherence to treatment by adolescents diagnosed with Juvenile Systemic Lupus Erythematosus. Four adolescents participated in the research, which had four stages: 1. Initial assessment; 2. Intervention, including Condition 1, with exposure to the manual followed by the self-monitoring record forms, and Condition 2, with a reversal order of these instruments; 3. Feedback; and 4. Follow-up. The data obtained with $24 \mathrm{~h}$ recall and self-monitoring record forms were quantified, allowing the calculation of the Treatment Adherence Index. Three participants showed an increase in this index after the use of self-monitoring records, regardless the exposition order of the instruments. The results of this research suggest that self-monitoring can assist in the installation of adherence behaviors, while manuals with instructions can help to maintain those behaviors, which would justify the combined use of these instruments.
\end{abstract}

Keywords: Lupus, adherence of treatment, manual, instruction, self-monitoring.

* Mailing address: Universidade Federal do Pará, Rua Augusto Corrêa, 1, Campus Universitário do Guamá, Belém, PA, Brazil 66075-110. Phones: +55 (91) 3201-7662/8542/8476. E-mail: fpa.vinha@gmail.com and comporta@ufpa.br

Article based on dissertation "Effects of combined use of manual and self-monitoring registers on reports of adherence to treatment of adolescents with Juvenile systemic lupus erythematosus" by Flávia Pinho Almeida - Universidade Federal do Pará / 2017.

Scholarship grant from the Brazilian Coordination for the Improvement of Higher Education Personnel (CAPES) from 03/2015 to 02/2017. Edital Ministério da Ciência, Tecnologia, Inovações e Comunicações (MCTI) / Conselho Nacional de Desenvolvimento Científico e Tecnológico (CNPq) / Ministério da Educação (MEC) /CAPES N ${ }^{\circ}$ 07/2011. 


\section{Efeitos de Instrução e de Automonitorização \\ na Adesão ao Tratamento do Lúpus Eritematoso Sistêmico Juvenil}

\section{Resumo}

Esta pesquisa avaliou os efeitos do uso combinado de instruções (via manual de educação em saúde) e de automonitorização (via formulários de registro) sobre a ocorrência de relatos de adesão ao tratamento por adolescentes com diagnóstico de Lúpus Juvenil. Quatro adolescentes participaram da pesquisa realizada em quatro etapas: 1. Avaliação inicial; 2. Intervenção, incluindo Condição 1, com exposição ao Manual seguido dos Formulários de Registro de Automonitorização, e Condição 2, com inversão da aplicação dos instrumentos; 3. Feedback; e 4. Follow-up. Os dados obtidos por meio de Recordatórios 24h e de registros em Formulários de Automonitorização foram quantificados, permitindo o cálculo do Índice de Adesão ao Tratamento. Três participantes melhoraram a adesão após a automonitorização, independentemente da ordem de apresentação dos instrumentos. Os resultados sugerem que a automonitorização pode auxiliar na instalação de comportamentos de adesão, enquanto o manual com instruções pode auxiliar na manutenção dos mesmos, o que justificaria o uso combinado destes instrumentos.

Palavras-chave: Lúpus, adesão ao tratamento, manual, instrução, automonitorização.

\section{Efectos de Instrucción y Automonitorización en la Adhesión al Tratamiento del Lupus Eritematoso Sistémico Juvenil}

\section{Resumen}

Esta investigación tuvo por objetivo evaluar los efectos del uso combinado de instrucciones (vía manual de educación en salud) y de automonitorización (vía formularios de registro) sobre la ocurrencia de relatos de adhesión al tratamiento por adolescentes con diagnóstico de Lupus Juvenil. Cuatro adolescentes participaron de la investigación que se realizó en cuatro etapas: 1. evaluación inicial; 2. Intervención, incluyendo - Condición 1, con exposición al Manual seguido de los Formularios de Registro de Automonitorización, y Condición 2, con inversión de la aplicación de los instrumentos; 3. Feedback; 4. Follow-up. Los datos obtenidos a partir del recordatorio de $24 \mathrm{~h}$ y de registros en los Formularios de Automonitorización fueron cuantificados, permitiendo el cálculo del Índice de Adhesión al Tratamiento. Tres participantes mejoraron la adhesión después de la automonitorización, independientemente del orden de presentación de los instrumentos. Los resultados sugieren que la automonitorización puede auxiliar en la instalación de comportamientos de adhesión, mientras que el manual con instrucciones puede auxiliar en el mantenimiento de los mismos, lo que justificaría el uso combinado de estos instrumentos.

Palabras clave: Lupus, adhesión al tratamiento, manual, instrucción, automonitorización.

Systemic Lupus Erythematosus (SLE) is a chronic autoimmune disease that can cause damages to various parts of the body (American College of Rheumatology, 2017a). Early manifestations by adolescence characterizes Juvenile Systemic Lupus Erythematosus (JSLE), with signs and symptoms, etiology and forms of treatment similar to SLE, although related to a more severe prognosis, especially when it affects kidneys, providing justification for studies that promote patient's adherence to treatment (American College of Rheumatology, 2017b). The condition affects mainly women of reproductive age (with incidence of 10:1 between the ages of 15 to 45), when production of estrogen, antibody selfforming, is high (da Costa \& Coimbra, 2014). 
JSLE treatment involves the association of a set of guidelines: medication administration, skin protection, well-balanced diet, physical exercises, vaccination, periodic medical examinations and frequent laboratory tests (Dunbar-Jacob, Houze, Kramer, Luyster, \& McCall, 2010; Gualano et al., 2011; Klack, Bonfá, \& Borba, 2012; Neder, Ferreira, \& Carneiro, 2017; Silva et al., 2010). To evaluate treatment efficacy the Systemic Lupus Erythematosus Disease Activity Index (SLEDAI) is used: a quantitative system of evaluation of lupus activity during the last 10 days, with score ranging between 0 (no characteristic of the disease is manifested) and 105 (severe manifestation of all characteristics) (Mikdashi \& Nived, 2015).

Adherence to treatment, considered emission of behaviors by the patient that coincide with the guidelines recommended by health care providers (World Health Organization, 2003), may be compromised by the treatment complexity. As well as, by unreliable verbal reports expressed by patients during examination by health providers (Malerbi, 2001); by variation in the intensity of symptoms during activation, or remission periods of disease (Sociedade Brasileira de Reumatologia, 2017), which could cause situations of non-exposure of patient to aversive contingencies resulting from this disease, further reducing emission of adherence behavior (Moritz, Hüunsche, \& Lincoln, 2014); and for lack of family support to the patient (Miller \& DiMatteo, 2013). As for JSLE, due to the gravity of the disease and its adverse consequences, adherence behaviors must be emitted regularly, and the patient should develop a management repertoire on the functionally related environmental variables to their response to adherence (Ferreira, 2006; Guimarães, Ferreira, Najjar, \& Moraes, 2015). Therefore, studies on instructional control, understood as the control set by rules, in other words, by antecedent verbal stimuli that specify contingencies, regardless of their immediate consequences (Albuquerque \& Paracampo, 2010), have contributed to studies on adherence to chronic diseases treatment (Najjar, Albuquerque, Ferreira, \& Paracampo, 2014).
Research has also suggested the importance of practices based on behavioral technologies to promote patient's adherence to treatment, as training for self-monitoring (Casseb \& Ferreira, 2012; Ferreira \& Fernandes, 2009) and analysis of contingencies when following treatment rules, and during the installation of preventive behavior and promotion of health (Bohm \& Gimenes, 2010; Najjar et al., 2014). According to Bohm and Gimenes (2008), self-monitoring is a class of observation behavior and systematic recording of the occurrence of determined responses by the individual that emits them, and from the contextual factors that evoke and maintain them. Studies have demonstrated its use in clinical contexts and research in the field of health aiming to promote adherence to treatment (Bohm \& Gimenes, 2012; Casseb \& Ferreira, 2012; Selvan, Thukral, Dutta, Ghosh, \& Chowdhury, 2017). They have also demonstrated gradual need for one-to-one instruction of selfrecording behavior through behavioral modeling (Donnelly \& Karsten, 2017).

Study by Martins, Ferreira, Silva, and Almeida (2015) indicated improvement in diet plan adherence after self-monitoring training for overweight children. However, the results have been attributed to the combined use of selfmonitoring with other instruments, including the manual with instructions on treatment. In health care, manuals are educational materials that provide information on certain illnesses including etiology, treatment and prognosis. Their aim is to help the patient and/or their families to identify symptoms, and the necessary care, by presenting rules in instruction format with justifications and tips on behavior that favor autonomy and control of the situation the patient is experiencing (Santos, Ribeiro, \& Monteiro, 2012). Since they are instruments that need social mediation, there is indication that these manuals should be used with the help of a health care professional to clarify possible doubts (Crepaldi, Rabuske, \& Gabarra, 2006).

Anotherinstrumentused is the 24-hour recall, where the patient provides detailed reports on the treatment occurred during the last 24-hours. 
It is inexpensive and can be filled out quickly. It may also be administered to the population with low level of education, based on manual or computerized procedure (Julián-Almárcegui et al., 2016; Ribeiro, Costa, Sobral, \& Florindo, 2011). The literature indicates occurrence of reports of patients who followed all treatment instructions, as well as on those not-following or partially following them, increasing reliability of data obtained through 24-hour recall (Azevedo \& Sampaio, 2003; Martins et al., 2015).

This research is justified because there are few studies on the use of behavioral technologies with JSLE population. It assessed the effects of the combined use of instructions (through education manual on health) and self-monitoring (using record forms) on the occurrence of reports on adherence to treatment by young people with JSLE. Emphasis has been given to the individual (the participant's and his/her treatment plan), procedural, interactional character, and life history of each patient, considering that these aspects are essential in the investigation of adherence to treatment and important in delineation of single subject used in Behavior Analysis- whose focus of analysis of results is centralized in behavior changes produced throughout experimental manipulations with the same subject (Andery, 2010; Velasco, GarciaMijares, \& Tomanari, 2010). It was also taken into consideration, the cautious hearing of verbal reports given by the participants and the importance of non-punitive hearing for control of nuances from these reports (Santos, Santos, \& Marchezini-Cunha, 2012).

\section{Method}

\section{Participants}

The study selected four female adolescents $(\mathrm{P} 1, \mathrm{P} 2, \mathrm{P} 3 \mathrm{e} \mathrm{P} 4)^{1}$, between 11 and 17 years of

During data collection period (Apr, 052016 to Jul, 18 2016), 87 adolescents received medical care at the pediatric rheumatology clinic. Only 21 of them (19 women and two men) had been diagnosed with JSLE, nine lived in other towns and seven were already participating in another age, living in the Metropolitan Region of BelémPA, diagnosed with JSLE being monitored at the pediatric rheumatology clinic of a university hospital (UH) who were not participating in other research whose objective was to improve treatment adherence. The adolescents excluded were those experiencing a crisis and/or going into crisis (an acute and severe manifestation of the disease) during data collection.

\section{Instruments}

Instruments used: (a) 24-hour recall (R24h): used to collect data on adherence behavior emitted during the last 24 hours and the contexts under which they occurred; (b) The pre-consultation interview schedule: adapted from Arruda and Zannon (2002), collected information on each participant, including historic of diagnosis, treatment, adherence, difficulties encountered, and family support to treatment; (c) Medical consultation observation form: used to help the researcher with the recording of instructions for treatment given by the doctor to each participant during consultation; (d) Interview script to be used after the medical consultation: employed to gather descriptions done by the participants on treatment indicated at each consultation, and whether instructions are easy or difficult to follow; (e) Chart analysis protocol: used to collect data recorded on each participant's medical record about the treatment indicating a clinical evaluation at the beginning and end of the research; (f) Manual "The Story of Mila: Living with Lupus" (Guimarães, Ferreira, Najjar, \& Moraes, 2014): elaborated by Guimarães et al. (2015), using a comic strip format, the manual character describes adherence behavior to JSLE treatment to be followed, including their justifications; (g) Self-monitoring registration form (SMRF): elaborated from instructions prescribed each participant by the doctor during the observed consultation, with the list of recommended behaviors and by columns

research whose aim was adherence improvement. One adolescent could not participate because she could not be available for the research. Therefore, four adolescents formed the study sample. 
to record their occurrences during an entire week; (h) Interview script to assess records made in SMRF: it was investigated the context in which the recorded behaviors were emitted after reading the registers, with explanations of occurrences and omissions, and presentation the positive social consequences through emission of accurate records and reports of adherence behavior to treatment; (i) Final interview script with feedback: gave each participant the main results achieved with the research and obtained their evaluations of the procedures performed and instruments used; and (j) follow-up script: checked the maintenance of adherence behaviors four weeks after the end of the intervention.

\section{Data Collection Procedure}

The procedure used was the single-subject research design with alternated treatment $(\mathrm{AB}-$ $\mathrm{CC}-\mathrm{BCC}$ and $\mathrm{ACCB}-\mathrm{CCB}$ ) to balance the order of presentation of instruments, from nine meetings with each one of the four participants, recorded in audio, through four stages:

Stage 1: Initial assessment. Meeting 1 consisted in: (a) administering the first 24-hour recall and pre-consultation questionnaire script; (b) consultation monitoring using the medical consultation observation form; (c) administering the post consultation interview script; and (d) initial survey of the chart analysis protocol.

Stage 2: Intervention. The participants were subjected to one among two experimental conditions according to the entry order in the research.

Condition 1-P1 and P3 (treatment ABCCBCC). Seven days after Meeting 1, Meeting 2 began with the administration of the second 24hour recall, used as baseline (BL) (A). Next, it was made an explanatory reading of Story of Mila Manual (B), checking the understanding of the text and clarifying possible doubts. In the end, the Manual was loaned to the participant. Meeting 3, after 14 days, started with the administration of the third 24-hour recall, and the return of the Manual to the researcher. Next, the participant received the first SMRF (C) with instructions to fill it in during week following the interview. Seven days later, during Meeting 4 the fourth 24-hour recall was administered, the records were assessed by the participant in the first SMRF, and made the second SMRF delivery (C). Seven days later, during Meeting 5, the fifth 24-hour recall was administered, the second SMRF records were assessed, and the Manual was delivered once again to the participant (B), asking her to tell the story to the researcher, who would intervene in cases of omissions/ mistakes during the narratives. In the end, the Manual was loaned to the participant once again. After 14 days, during Meeting 6, after the administration of the sixth 24-hour recall and return of the Manual, the participant received the third SMRF (C). Seven days later, during Meeting 7, the seventh 24-hour recall was administered, the third SMRF records were assessed, and the fourth SMRF delivered (C). Seven days later, during Meeting 8 , the eight 24-hour recall was administered and the fourth SMRF records assessed.

Condition 2 - P2 and P4 (treatment ACCB-CCB). Initially, under Condition 2, the participants completed the second 24-hour recall to be used as baseline (A). Next, they were subjected to intervention according to SMRF order (CC) followed by the Manual (B), obeying the same instructions and intervals between meetings held with the participants of Condition 1.

Stage 3: Feedback. On both conditions, the final interview transcript was administered with feedback, at the end of Meeting 8.

Stage 4: Follow-up. Twenty eight days after the interventions, the nineth 24-hour recall and the follow-up script were administered during Meeting 9.

Finally, the chart analysis protocol was filled, and the rheumatologist interpreted each participant's clinical and laboratory data obtained during the research.

\section{Data Analysis Procedure}

The data collected through interview scripts, after a literal transcription of the participants' speech, were assessed according to the subject 
discussed. The information obtained from the medical consultation form was organized by category, supporting the SMRF construction and the record analyzes they contained, as well as the analyses from reports gathered by the 24-hour recalls.

Based on studies that used calculus to obtain the Treatment Adherence Index (Gomes, Ferreira, \& de Souza, 2012; Martins et al., 2015; Neder et al., 2017), in this research, calculation was done by assigning the value of 1 for the corresponding reports following the instructions prescribed by the doctor; value 0.5 for reports indicating irregular following of instructions and 0 for reports showing that medical instructions had not been followed. The sum of the values was used to calculate the Treatment Adherence Index - TAI (the number of instructions followed x 100/ total number of instructions). This way, two TAI groups were obtained: a general one - relating to the calculus of adherence to treatment as a whole - regarding the use of medication, food plan and use of sun protection. The first administration of the 24-hour recalls was disregarded in these calculations, considering the second one as the baseline (A) due to reliability in the access to the instructions prescribed to each participant during the observed medical consultation. To check the reliability of these points, two external assessors made a blind counting of ten 24-hour recalls (31.25\% of the 24 -hour recalls) and eight SMRFs (50\% of the total SMRFs) randomly selected, based on the same rules for punctuation used by the researcher. The levels of reliability obtained were higher than $75 \%$ for 24 -hour recalls, or higher than $83.92 \%$ for SMRFs, indicating a good level of reliability (Fagundes, 1982). The TAI were organized in figures according to single-subject research design, permitting analysis through visual inspection of effects caused by alternated treatments and verification of accumulated effects.

The information collected from 24-hour recalls and Interview scripts for analyses of SMRF responses permitted to make macro analyses of the contexts where behavior had been emitted based on the description of each case. Finally, the analyses and interpretation done by the rheumatologist using laboratory and clinical data of each participant permitted to calculate the SLEDAI values in the beginning and at the end of the research, enabling verification of clinical improvement and its coincidence with the adherence reports.

\section{Ethical Procedures}

The project was approved by the Research Ethics Comittee involving human beings (according to resolution 466/12 of the National Health Council/ Ministry of Health), Institute of Health Science from a public university in Brazil, Certificate of Presentation for Ethical Consideration CAAE 52274615.8.0000.0018, Opinion $\mathrm{N}^{\circ} 1,456.036$, all research risks and benefits explained to the adolescents and their respective parents and guardians during the Informed Consent reading.

\section{Results}

Figure 1 shows the general index values for adherence to treatment obtained from 24-hour recalls according to order of presentation of the instruments under each Condition.

In Baseline (A), all four participants' IAT were below $50 \%$, suggesting low adherence to the prescribed instructions during medical consultation. Initial exposure to the Manual (B) did not lead to an increase in P1's and P3's index. After exposure to the Self-monitoring Form (C), participants P1, P2 and P4 increased their index, despite the sequence in which this instrument was presented. P2's and P4's index remained stable after exposure to the Forms and the Manual, with values above those achieved in Baseline. P3 was the only participant whose IAT remained below $30 \%$ in all stages of the research.

Figure 2 shows values of IAT for each participant by treatment category (medication; diet plan; sun protection) according to the condition. 
P1

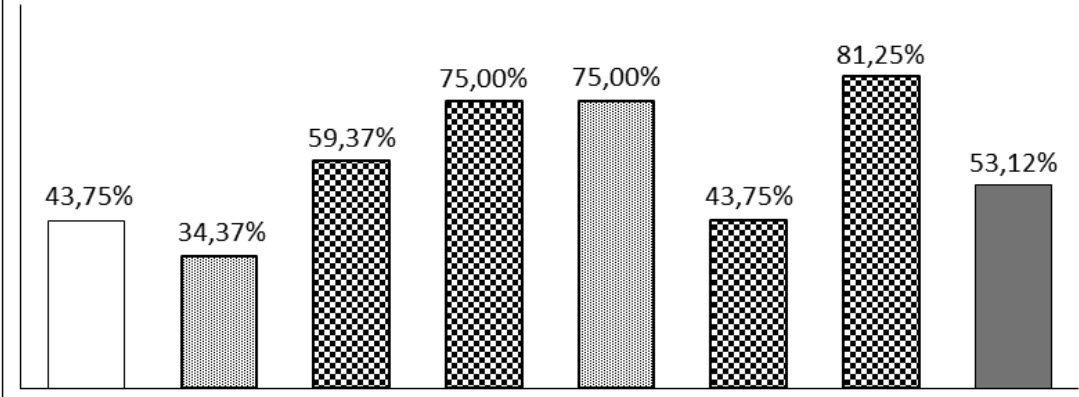

P3

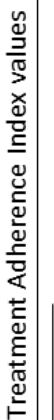
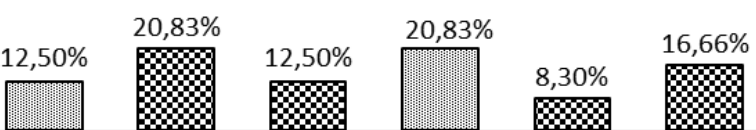

$12,50 \%$

$\square B L-(A)$

P2

田 After the Manual - (B)

2
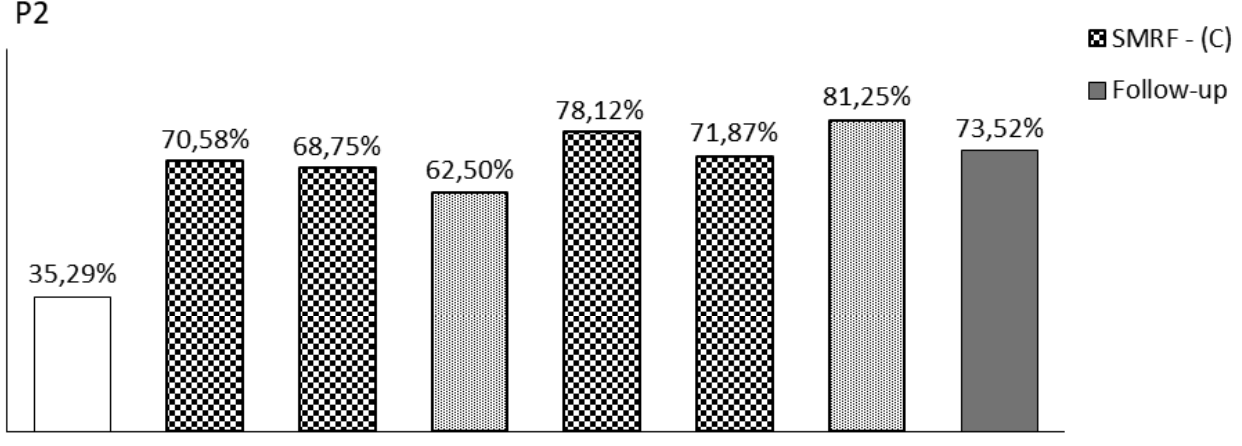

P4

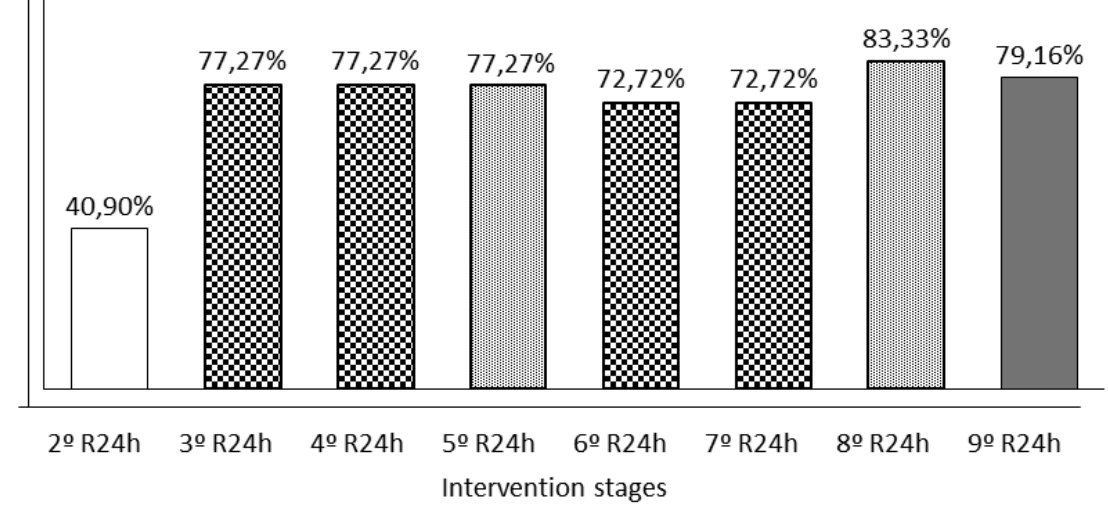

Figure 1. General Treatment Adherence Index according to order of presentation of instruments at each experimental condition.

Note. TAI scores based on administration of 24-hour recall with participants in Condition 1 (P1 and P3) and Condition 2 (P2 and P4) in Baseline (A), after the Manual (B), after Self-monitoring registration form (C) and Follow-up. 


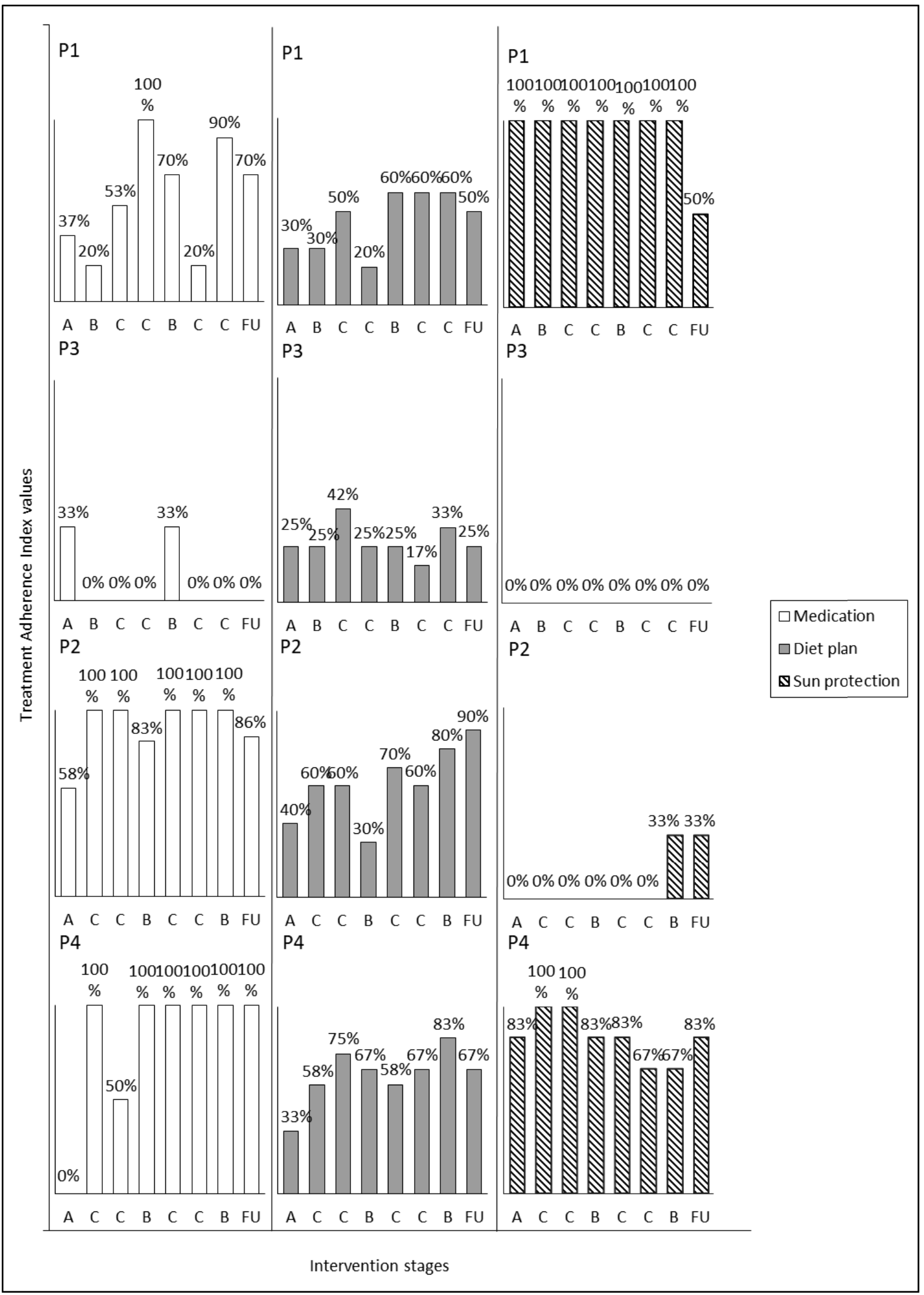

Figure 2. Treatment Adherence Index by treatement category, in accordance with the experimental condition.

Note. TAI scores based on administration of 24-hour recall with participants in Condition 1 (P1 and P3) and Condition 2 (P2 and P4) in Baseline (A), after the Manual (B), after Self-monitoring registration form (C) and Follow-up. 
As for P1, use of sun protection resulted in the best adherence among all treatment categories, with a $100 \%$ at all research stages, except in follow-up. The TAI related to use of medication ranged from $20 \%$ to $100 \%$, while the index related to following the diet plan remained stable at $60 \%$ after the second exposure to the Manual (B). On the other hand, P3 achieved very low levels in all treatment categories. She did not use any sun protection in all stages of the research. In regard to medication, $\mathrm{P} 3$ 's index had records in only two (both $33 \%$ ) of the nine meetings she attended.

P2 and P4 had the best adherences to use of medication (index equal to $100 \%$ in most meetings) and to the diet plan. Unlike P2, P4 achieved high index by using sun protection. On follow-up, both of them had scores above that obtained on the baseline for each one of the treatment categories.

\section{Macro Analysis of the Cases}

\section{Condition 1 (ABCC-BCC).}

Participant P1. P1, 15 years old, high school freshman, lived in the Metropolitan Region of Belém with her mother and a sister. Two years and a month ago, she was referred to the UH rheumatology clinic where she was diagnosed with JSLE. She has been under treatment and had 11 medical consultations since then. When the research began, she had wrist arthritis, lymphopenia and SLEDAI 4. She admitted she had difficulties to follow instructions on dietary reeducation and use of medications. She did not know the meaning of "chronic disease" (e.g. "I have heard the doctor mention it, but I cannot remember it very well'), as well as the JSLE prognosis for not following instructions (e.g. "I do not know what may happen, because I have not felt anything until now").

As for treatment adherence, in BL (A), the use of sun protection was strictly followed by P1 (TAI $=100 \%)$; however, she had difficulties to follow the diet plan instructions (TAI $=30 \%$ ) and medication administration (TAI $=37 \%$ ), even though she confirmed that she had both her mother and sister's support (e.g. "My mother always helps me with medication" and "my sister cooks a special diet for me"). The high score regarding the use of sun protection related to arrangements of contingencies that made adherence easier (e.g. "I think that, since I left the sun protector at grandmother's . . If I do not apply it there, I end up not applying it at all"; "Before I leave home, I check my handbag, I saw the sun protector and applied it"). Another factor that might have helped adherence to use of sun protection was related to P1's acne treatment (e.g. "I am undergoing treatment for acne ... and if I am exposed to the sun, I get skin stain or rashes, which makes me use more sun protection").

P1 related difficulties to adapt to drug treatment in her daily routine (e.g. "I forgot my medicine because I left home in a hurry, I forgot to bring it" and "This week was a little more difficult because I was very busy at school . . and I sometimes forgot them [the medications]"). She also reported difficulties to change her eating patterns to follow the instructions given by the doctor (e.g. "I find it very difficult to eat vegetables").

P1 initial exposition to the Manual (B) did not result in changes in adherence to medication (TAI was reduced to $20 \%$ ) or the diet plan (TAI remained at $30 \%$ ). Her reports concerning this instrument showed that, despite knowing the manual importance, and having read it twice, it did not add new information to her on the disease and its treatment. However, improvement in adherence was observed after the use of SMRF (C), especially in regard to the use of medication (TAI $=53 \%$ and $100 \%$ ). P1 attributed the use of SMRF to why she started to have new adherence behavior, besides emitting more often those behaviors already installed in her repertoire (e.g. "Whenever I came here, I took home those papers [SMRF] and eventually got used [to the treatment]").

The participant reported improvement in JSLE after the intervention (e.g. "Before, I felt pains in my knee ... now I rarely do, and they are very mild"), confirming the medical evaluation of improvement in articular mobility and normalization of haematological (lymphopenia) 
parameters, with 0 SLEDAI score by the end of the research.

Participant 3. P3, 17 years old, diagnosed with JSLE seven years ago. She was a highschool senior, lived in Belém with her parents, sister and grandmother. She had already been to 11 medical consultations at UH clinic; however, she had not seen a doctor for two years (when her mother had a breast cancer relapse). When the research began, she declared that she did not know the chronic character of the JSLE. She declared that the disease was under control, without symptoms, even though the initial clinical evaluation had indicated the presence of acute arthritis in the wrist and SLEDAI 4. She indicated that the pains had decreased after she started treatment; however, she informed that she had difficulties to follow the diet plan (e.g. "It is difficult to control it ... I had regular meals without any restriction"). She also informed that her mother helped her follow the treatment (e.g. "mother reminds me of things, she reprimands me when necessary").

During intervention, P3's adherence to the diet was low (TAI below 50\%). Initially, she could not describe which diet instructions had been prescribed (e.g. "I do not remember the diet"). Even after she had been exposed to the Manual (B) instructions, when it was verified that she had had a better understanding of the food plan, she did not adhere to the rules (e.g. "I think ham is out of question because it is salty; dinner also, because I cannot eat much bread"). She mentioned social contexts that made adherence more difficult, such as the eating out habit of the family and other occasions when she had meals at friends' homes.

P3's difficulties to follow instructions related to sun protection (whose adherence was not observed during the study), and to medication (with initial score at 33\% observed after intervention, equal to that obtained in BL) were demonstrated during the reports: "I never remember to use sun protection; sometimes I do, but then I think 'I am not going to use it' because I do not like the greasy thing"; "I forgot to take my medication, yesterday; I left home in a hurry and did not take it".
She reported she had difficulties in filling out SMRF (C) in her daily routine (e.g. "I forgot to fill it out" and "This one was filled out in a single day because I had had a very busy week"). As for the Manual (B), she recognized its importance as a guide to the patients (e.g. "It explains it all very well. It also explains things that I did not remember or that I did not know how to say it . . . even though they did not have any new information"), she requested an adaptation of the story should to juveniles.

Despite P3's low scores at all stages, by the end of the research, it was observed an articular mobility improvement, with SLEDAI 0, suggesting control of JSLE symptoms, according to the rheumatologist's medical evaluation.

\section{Condition 2 (ACCB-CCB).}

Participant P2. P2, 13 years old, lived with her parents, a sister and a niece in a small town and needed to move to the Metropolitan Regions of Belém and live with an aunt, to be able to see a doctor at UH, which made her stop attending school during the research. For four years and five months, P2 went 22 times to the clinic for medical consultations and three more times during the research. In the beginning, she had polyarthritis of the hip, wrist, feet and ankle, afternoon fever, malar erythema, hematuria and SLEDAI 12. She was aware of JSLE as a chronic disease, identifying the long term damages caused by low adherence to treatment. She expected to live with her nuclear family as soon as she received medical orientation (e.g. "I hope the doctor prescribes the medications and that I may be able to go home"). Then, she stated that she followed the orientations concerning medication administration, but that she found it difficult to use sun protector and to engage in physical activity. She emphasized that she received help from both her mother and sister (e.g. "Sometimes, I am sad, my sister calls $m e$, and then I feel better"). She also receives a minimum wage monthly benefit from Federal government due to the JSLE.

For BL (A), P2's general TAI was equal to $35.29 \%$. After exposition to SMRF (C), she had an increase in score concerning the use of 
medications (100\%) and diet plan $(60 \%)$; on the other hand, she continued her non adherence to sun protector use (e.g. "It is because I do not like sun protector. . . I do not like the smell, its unpleasant odor makes me feel awful"). Only after the two last meetings and after an exposition on the combined effect of SMRF (C) with the Manual (B), there was a record of sun protection use with TAI equal to $33 \%$ (e.g. "The forms helped me use sun protection").

In regard to use of medications, her reports indicated stability in the adherence repertoire (e.g. "Considering the time I have been taking medication, I already got used to it"). On the subject of food, P2 specified the observed benefit resultant from the regularity in fractioning the meals, especially breakfast (e.g. "I like breakfast, otherwise I have stomach ache").

The participant did not have any difficulty with the use of SMRF (C) (e.g. "It was easy. I had no problems" and "I wrote all the notes alone, without any help"). As for the Manual (B), she showed interest in the story and in passing on the information on lupus to other people around her, besides recognizing the acquisition of new knowledge about the disease.

By the end of the research, P2's clinical features had improved, but maintained articular mobility difficulties, obtaining an 8 for SLEDAI.

Participant P4. P4, 11 years old, had been diagnosed two months before. She lived in the Metropolitan Region of Belém with two aunts, two grandmothers, and was a 6 th grade student. During the initial clinical evaluation, she had wrist arthritis, and her urine test results showed hematuria. She also had malar erythema, and a SLEDAI 10. She knew that JSLE was a chronic disease (e.g. "I know the disease has no cure. . . but that it can be controlled"), and she could identify the damages it caused (e.g. "I was afraid because I had much pain, I could not move"). She expected to improve with treatment in order to return to her karate practices. She said she followed instruction on use of sun protection, counting on the help of her grandmothers and aunts to follow the orientations on skin care and use of medications. She declared that she found it difficult to change her diet habits (e.g. "When I am hungry... I want to eat anything") and stop her physical activities (e.g. "I cried a lot when stopped my karate practices").

For BL (A), P4's general TAI was equal to $40.90 \%$, which increased in relation to other treatment instructions after using SMRF (C). The score values remained above $72 \%$ during all meetings held at the time. After intervention, P4 described both qualitative and quantitative improvement in food ingestion (e.g. "Now, I eat less heavy meals"), indicating better external control for her diet behavior (e.g. she [the grandmother] "will not let me eat much. I used to have a second helping, now they will not let me have it").

In regard to SMRF (C), P4 had difficulties to fill it out in the beginning, which she overcame during the training process (e.g. "In the beginning, it was difficult because I thought it was boring, but . . I eventually got used to $i t$ '). She reported that she had cleared her doubts in relation JSLE while reading the Manual (B), and shared its information with her classmates at school. She observed positive changes when she followed orientations on medication, the use of sun protection and diet plan. She received support from her family during the process.

In the final medical evolution, $\mathrm{P} 4$ improved her clinical features, but she maintained difficulties in articular mobility, obtaining SLEDAI score of 4.

\section{Discussion}

All participants' TAI were below $50 \%$ in BL (A), despite the time of diagnosis or the time of monitoring in the UH rheumatology clinic, suggesting that the routine of medical attention to which they had been exposed in the beginning of the research had not been enough to promote adherence. When comparing with $\mathrm{BL}$ value, it was observed increase in TAI after using SMRF by P1, P2 and P4, despite the order in which they had been presented. As for $\mathrm{P} 2$ and $\mathrm{P} 4$ (Condition 2 - ACCB-ACCB), increase in score was obtained immediately after the first administration of SMRF (C), preceding the Manual (B) presentation. For P1 (Condition 1 - 
ABCC-ABCC), increase was also obtained with the first SMRF administration, which, in this case, was after the first Manual presentation.

According to Bohm and Gimenes (2010, 2012) and Selvan et al. (2017), recordings in self-monitoring forms favor installation of selfobservation behavior, which are requirements for contingency arrangements related to adherence to treatment, as observed by Neder et al., (2017). In this study P1, P2 and P4's reports indicated good acceptance to do the recordings in SMRFs, despite imprecisions; while P3, with the lowest TAI among the participants during the research, reported that she had had difficulty, and even refused to fill out the SMRF, which could explain the results obtained.

On the other hand, the existing contingencies may make behavior recording difficult as they occur, which may lead to imprecision according to Bohm and Gimenes (2008). This study sought to minimize this problem with the combined use of 24-hour recall and Interview script for analysis of the recordings made in SMRF. Therefore, the presence of records and reports on treatment adherence and non-adherence were observed, suggesting their possible fidelity (Dunbar-Jacob et al., 2010). The researcher's non-punitive hearing may have favored the occurrence of accurate reports (Malerbi, 2001; Santos, Santos, et al., 2012).

P3 reported more difficulties in filling out the self-monitoring records than the other participants. Her reports suggest that providing the record forms may not be enough; it is necessary to create a more simple form, using behavior shaping teaching to record in degrees of increasing complexity, as suggests individualized learning in applied behavior analysis (Bohm \& Gimenes, 2008; Donnelly \& Karsten, 2017). This situation can be investigated in future studies, where different types of record forms are presented according to their degree of complexity, aiming the installation of accurate recording behaviors in participants who have problems filling out the forms.

The maintenance of high TAI obtained by P1, P2 e P4 during research can be attributed to the combined effect of use of instruments.
A second Manual exposure to $\mathrm{P} 1$, and a first exposure after the first two SMRF for P2 and $\mathrm{P} 4$, helped to maintain a high TAI during the weeks when the self-monitoring forms were temporarily suspended. Those data indicated that the use of SMRF may be necessary to install behavior adherence, while the use of the Manual with justifications may help their maintenance, justifying the combined use of these instruments in treatment adherence, as suggested by Martins et al. (2015).

Manuals may improve patient's knowledge on the disease (Crepaldi et al., 2006; Santos, Ribeiro, et al., 2012) by describing the treatment instructions and presenting justifications to follow them. However, this strategy may not be enough to install adherence behavior, and to cause behavior changes in the long term, as demonstrated in a study by Brasiliense, Benchaya, and Ferreira (2014). Such fact indicates need for the combined use with other instruments from behavioral technology.

As for clinical features, the evaluation made by the rheumatologist showed that all participants had an improvement, justifying decrease in SLEDAI scores for each participant by the end of the research when compared with the scores in the beginning. Improvement observed for P1, P2 and $\mathrm{P} 4$ coincide with an increase in TAI observed during the research. Despite a decrease in the three participants' scores for their follow-up, in relation to those measured shortly after the end of the interventions, they were all greater than those shown in BL, indicating benefits with the combined use of instruments, associating with an improvement in clinical status by the end of the study. Decrease in follow-up scores may suggest difficulties in maintaining behavior adherence after removal of social control exercised by the researcher, a situation also observed in Martins et al. (2015), which could be investigated in monitored long-term longitudinal studies.

As for P3, the lack of perception of JSLE signals and symptoms by the participant during the research may be associated with the low TAI. Non exposition to aversive contingencies when the disease is triggered may decrease the probability of emission of adherence behavior 
(Malerbi, 2001; Moritz et al., 2014), which was verified in P3's reports on reasons not to follow treatment. P3's reports also indicated difficulties in adapting to routine due to the characteristics of treatment and lack of family support, which may have contributed to low adherence. Malerbi (2011) and Miller and DiMatteo (2013) pointed those same factors as impediments to chronic disease treatment.

Aiming an increase in representativeness and generalities of conclusions of this study, it is suggested, based on the text by Velasco et al. (2010), that direct replications should be carried out (whenever condition is possible to repeat this study maintaining stable the procedures and parameters used here, including the participation of male patients) and/or systematic replications (when functional relationship are repeated under circumstances different from those used here), providing justification to carry out multicentric studies. Therefore, the use of these instruments could be expanded to health professionals that monitor similar cases, using the same routine with patients at the clinics.

\section{References}

Albuquerque, L. C., \& Paracampo, C. C. P. (2010). Análise do controle por regras. Psicologia USP, 21(2), 253-273. doi: 10.1590/S010365642010000200004

American College of Rheumatology. (2017a). Lupus. Retrieved from http://www.rheumatology.org/IAm-A/Patient-Caregiver/Diseases-Conditions/ Lupus

American College of Rheumatology. (2017b). Systemic Lupus Erythematosus (Juvenile). Retrieved from https://www.rheumatology.org/IAm-A/Patient-Caregiver/Diseases-Conditions/ Systemic-Lupus-Erythematosus-Juvenile

Andery, M. A. P. A. (2010). Métodos de pesquisa em Análise do Comportamento. Psicologia USP, 21(2), 313-342. doi: 10.1590/S010365642010000200006

Arruda, P. M., \& Zannon, C. M. L. C. (2002). Tecnologia comportamental em saúde. Adesão ao tratamento pediátrico da doença crônica: Evidenciando o desafio enfrentado pelo cuidador. Santo André, SP: ESETec.
Azevedo, D. V., \& Sampaio, H. A. C. (2003). Consumo alimentar de gestantes adolescentes atendidas em serviço de assistência pré-natal. Revista de Nutrição, 16(3), 273-280. doi: 10.1590/S1415-52732003000300005

Bohm, C. H., \& Gimenes, L. S. (2008). Automonitoramento como técnica terapêutica e de avaliação comportamental. Revista Psicolog, 89-101. Retrieved from http://www.cemp.com.br/arquivos/39088_73.pdf

Bohm, C. H., \& Gimenes, L. S. (2010). Síndrome do Intestino Irritável: Um exercício em Análise Funcional do Comportamento. Interação em Psicologia, 14(2), 163-174. doi: 10.5380/psi. v14i2.15600

Bohm, C. H., \& Gimenes, L. S. (2012). Reatividade ao automonitoramento em uma portadora da síndrome do intestino irritável. Psicologia: Teoria e Pesquisa, 28, 293-301. doi: 10.1590/ S0102-37722012000300005

Brasiliense, I. C., Benchaya, I. D., \& Ferreira, E. A. P. (2014). Efeitos de um manual de instrução sobre o repertório de comportamentos de acompanhantes de crianças com câncer. Interação em Psicologia, 18(3), 251-261. doi: 10.5380/psi. v18i3.30854

Casseb, M. S., \& Ferreira, E. A. P. (2012). Treino em automonitoração e comportamentos de prevenção em diabetes Tipo 2. Estudos de Psicologia (Campinas), 29, 135-142. doi: 10.1590/S0103166X2012000100015

Crepaldi, M. A., Rabuske, M. M., \& Gabarra, L. M. (2006). Modalidades de atuação do psicólogo em psicologia pediátrica. In M. A. Crepaldi, M. B. M. Linhares, \& G. B. Perosa (Eds.), Temas em psicologia pediátrica (pp. 13-55). São Paulo, SP: Casa do Psicólogo

Da Costa, L. M., \& Coimbra, C. C. B. E. (2014). Lúpus Eritematoso Sistêmico: Incidência e tratamento em mulheres. Revista Uningá Review, 20(1), 81-86. Retrieved from http://revista.uninga.br/ index.php/uningareviews/article/view/1562

Donnelly, M. G., \& Karsten, A. M. (2017). Effects of programmed teaching errors on acquisition and durability of self-care skills. Journal of Applied Behavior Analysis, 50, 511-528. doi: 10.1002/ jaba.390

Dunbar-Jacob, J., Houze, M. P., Kramer, C., Luyster, F., \& McCall, M. (2010). Adherence to medical advice: Processes and measurement. 
In A. Steptoe (Ed.), Handbook of behavioral medicine: Methods and applications (pp. 8395). New York: Springer.

Fagundes, A. J. F. M. (1982). Descrição, definição e registro de comportamento (pp. 67-77). São Paulo, SP: EDICON.

Ferreira, E. A. P. (2006). Adesão ao tratamento em psicologia pediátrica. In M. A. Crepaldi, M. B. M. Linhares, \& G. B. Perosa (Eds.), Temas em psicologia pediátrica (pp. 147-189). São Paulo, SP: Casa do Psicólogo

Ferreira, E. A. P., \& Fernandes, A. L. (2009). Treino em auto-observação e adesão à dieta em adulto com diabetes Tipo 2. Psicologia: Teoria e pesquisa, 25(4), 629-636. doi: 10.1590/S010237722009000400019

Gomes, D. L., Ferreira, E. A. P., \& de Souza, C. M. C. (2012). Automonitoramento e adesão a dois tipos de regras nutricionais em adultos com diabetes Tipo 2. Acta Comportamentalia, 20(3), 327-342. Retrieved from http://pepsic.bvsalud.org/scielo.php?script $=$ sci_arttext\&pid=S0188-81452012000300006

Gualano, B., Pinto, A. L. S., Perondi, M. B., Roschel, H., Sallum, A. M. E., Hayashi, A. P. T., Solis, M. Y., \& Silva, C. A. (2011). Efeitos terapêuticos do treinamento físico em pacientes com doenças reumatológicas pediátricas. Revista Brasileira de Reumatologia, 51(5), 484-496. doi: 10.1590/ S0482-50042011000500008

Guimarães, M. L. L., Ferreira, E. A. P., Najjar, E. C. A., \& Moraes, A. J. P. (2014). A história de Mila: Convivendo com o Lúpus. Retrieved from http://www.sbp.com.br/fileadmin/user_upload/ pdfs/CartilhaLupos_EMCURVAS_FINAL_ WEB.pdf

Guimarães, M. L. L., Ferreira, E. A. P., Najjar, E. C. A., \& Moraes, A. J. P. (2015). Elaboração de manual de orientações para pacientes com lúpus eritematoso sistêmico juvenil. Mudanças - Psicologia da Saúde, 23(2), 59-67. doi: 10.15603/2176-1019/mud.v23n2p59-67

Julián-Almárcegui, C., Bel-Serrat, S., Kersting, M., Vicente-Rodriguez, G., Nicolas, G., Vyncke, K., ...Huybrechts, I. (2016). Comparison of different approaches to calculate nutrient intakes based upon 24-h recall data derived from a multicenter study in European adolescents. European Journal of Nutrition, 55, 537-545. doi: 10.1007/s00394-015-0870-9
Klack, K., Bonfa, E., \& Borba, E. F., Neto. (2012). Dieta e aspectos nutricionais no lupus eritematoso sistêmico. Revista Brasileira de Reumatologia, 52(3), 384-408. doi: 10.1590/ S0482-50042012000300009

Malerbi, F. E. K. (2001). Estratégias para aumentar a adesão em pacientes com diabetes. In $\mathrm{H}$. J. Guillardi (Ed.), Sobre Comportamento $e$ Cognição. Expondo a variabilidade (pp. 126131). Campinas, SP: ESETec.

Malerbi, F. E. K. (2011). Adesão ao tratamento, importância da família e intervenções comportamentais em diabetes. In Sociedade Brasileira de Diabetes, Diabetes na prática clínica (módulo 3). Retrieved from http://www. diabetes.org.br/ebook/component/k2/item/53adesao-ao-tratamento-importancia-da-familia-eintervencoes-comportamentais-em-diabetes

Martins, L. C. C. O., Ferreira, E. A. P., Silva, L. C. C., \& Almeida, F. P. (2015). Seguimento de regras nutricionais em crianças com excesso de peso. Psicologia: Teoria e Pesquisa, 31(1), 33-41. doi: 10.1590/0102-37722015011465033041

Mikdashi, J., \& Nived, O. (2015). Measuring disease activity in adults with systemic lupus erythematosus: The challenges of administrative burden and responsiveness to patient concerns in clinical research. Arthritis Research \& Therapy, 17(183), 1-10. doi: 10.1186/s13075-015-0702-6

Miller, T. A., \& DiMatteo, M. R. (2013). Importance of family/social support and impact on adherence to diabetic therapy. Diabetes, Metabolic Syndrome and Obesity: Targets and Therapy, 6, 421-426. doi: 10.2147/DMSO.S36368

Moritz, S., Hüunsche, A., \& Lincoln, T. M. (2014). Nonadherence to antipsychotics: The role of positive attitudes towards positive symptoms. European Neuropsychopharmacology, 24, 17451752. doi: 10.1016/j.euroneuro.2014.09.008

Najjar, E. C. A., Albuquerque, L. C., Ferreira, E. A. P., \& Paracampo, C. C. P. (2014). Efeitos de regras sobre relatos de comportamentos de cuidados com os pés em pessoas com diabetes. Psicologia: Reflexão e Crítica, 27(2), 341-350. doi: 10.1590/1678-7153.201427215

Neder, P. R. B., Ferreira, E. A. P., \& Carneiro, J. R. (2017). Adesão ao tratamento do lúpus: Efeitos de três condições de intervenção. Psicologia, Saúde \& Doenças, 18(1), 203-220. doi: $10.15309 / 17 \mathrm{psd} 180117$ 
Ribeiro, E. H., Costa, E. F., Sobral, G. M., \& Florindo, A. A. (2011). Desenvolvimento e validação de um recordatório de 24 horas de avaliação da atividade física. Revista Brasileira de Atividade Física e Saúde, 16(2), 132-137. doi: 10.12820/ RBAFS.V.16N2P132-137

Santos, A. K., Ribeiro, A. P. G., \& Monteiro, S. (2012). Hanseníase e práticas da comunicação: Estudo de recepção de materiais educativos em um serviço de saúde no Rio de Janeiro. Interface - Comunicação, Saúde, Educação, 16(40), 205 218. doi: 10.1590/S1414-32832012005000018

Santos, G. M., Santos, M. R., \& Marchezini-Cunha, V. (2012). A escuta cautelosa nos encontros iniciais: A importância do clínico analíticocomportamental ficar sob controle das nuances do comportamento verbal. In N. B. Borgest \& F. A. Cassas (Eds.), Clínica Analítico Comportamental: Aspectos teóricos e práticos (pp. 138-146). Porto Alegre, RS: Artmed

Selvan, C., Thukral, A., Dutta, D., Ghosh, S., \& Chowdhury, S. (2017). Impact of self-monitoring of blood glucose log reliability on long-term glycemic outcomes in children with type 1 diabetes. Indian Journal of Endocrinology and Metabolism, 21, 382-326. doi: 10.4103/ijem. IJEM_342_16

Silva, C. A. A., Terreri, M. T. R. A., Aikawa, N. E., Carvalho, J. F., Pileggi, G. C. S., Ferriani, V. P. L., ...Bastos, W. A. (2010). Prática de vacinação em crianças com doenças reumáticas. Revista Brasileira de Reumatologia, 50(4), 351-361. doi: 10.1590/S0482-50042010000400002
Sociedade Brasileira de Reumatologia. (2017). Lúpus Eritematoso Sistêmico (LES). Retrieved from https://www.reumatologia.org.br/ doencas/principais-doencas/lupus-eritematososistemico-les/

Velasco, S. M., Garcia-Mijares, M., \& Tomanari, G. Y. (2010). Fundamentos metodológicos da pesquisa em Análise Experimental do Comportamento. Psicologia em Pesquisa, 4(2). 150155. Retrieved from http://www.ufscar.br/ecce/ wp-content/files_flutter/1304450320Velascoetal.2010PsicologiaemPesquisa.pdf

World Health Organization. (2003). Adherence to long-term therapies: Evidence for action. Geneva. Retrieved from http://www.who.int/ chp/knowledge/publications/adherence_full_ report.pdf
Received: $30 / 10 / 2017$

$1^{\text {st }}$ revision: $25 / 02 / 2018$

Accepted: 09/04/2018

(c) BY The Author(s), 2018. Open Access. This article is distributed under the terms of the Creative Commons Attribution 4.0 International License (http://creativecommons.org/licenses/by/4.0/), which permits unrestricted use, distribution, and reproduction in any medium, provided you give appropriate credit to the original author(s) and the source, provide a link to the Creative Commons license, and indicate if changes were made. 